\title{
EFFECTS OF RUBBER PLANTATION POLICY ON WATER RESOURCES AND LANDUSE CHANGE IN THE NORTHEASTERN REGION OF THAILAND
}

\author{
Aweewan Mangmeechai ${ }^{*}$ \\ ${ }^{1}$ National Institute of Development Administration, Bangkok, Thailand \\ *Corresponding author: aweewan.m@nida.ac.th \\ Received: November 9 ${ }^{\text {th }}, 2019$ / Accepted: May 10 th, 2020 / Published: July $1^{\text {st }}, 2020$ \\ https://DOI-10.24057/2071-9388-2019-145
}

\begin{abstract}
The Thai government launched Phase 3 of its Rubber Plantation Project in 2011 aiming to expand the total area of new plantations to 128,000 ha. The northeastern region contains the largest areas for new rubber plantation areas, yet it is known to have unfertile areas and regular encounters with water scarcity during summer. This leads to research questions as to how the policy affects land and water use in the country. This study shows that the water requirement of rubber trees is $14,221 \mathrm{~m}^{3} / \mathrm{ha}$ /year which is higher than that of other local crops (e.g., rice, cassava, sugarcane, and corn). Thus, irrigation systems must be utilized during certain months. The land use changes from the cultivation of edible crops to rubber do not threaten the amount of food available for domestic consumption since Thailand generally exports more of its crops than it consumes. From this policy, total rubber yield would increase to $742 \mathrm{M} \mathrm{kg}$ and rice, corn, and cassava would disappear about $1613 \mathrm{M} \mathrm{kg}$ (24\% of the total amount of rice exported in 2012), 7837 M kg, 8926 M kg, respectively.The government should provide a better plan on crop water requirements suitable for each region and knowledge on increasing crop-per-drop efficiency to all farmers.
\end{abstract}

KEY WORDS: Rubber water consumption; Agricultural policy; Lang use; Irrigation system

CITATION: Aweewan Mangmeechai (2020). Effects Of Rubber Plantation Policy On Water Resources And Landuse Change In The Northeastern Region Of Thailand. Geography, Environment, Sustainability, Vol.13, No 2, p. 73-83

https://DOI-10.24057/2071-9388-2019-145

ACKNOWLEDGEMENTS: This research was supported by Thai National Research Council. The author thanks associate professor Prasert Pavasant and terms for assistance with for data collection and comments that greatly improved the manuscript. They may not agree with all of the interpretations/conclusions of this paper.

Conflict of interests: The authors reported no potential conflict of interest.

\section{INTRODUCTION}

Water is becoming a scarce resource for agricultural plantations. Most of the water (up to 90\%) provided for domestic purposes can be reused and recycled, while most of the water (40-90\%) provided to agriculture to grow food is consumed (evapotranspired) and cannot be re-used (Rijsberman 2006). Small farmers and the poor are particularly disadvantaged and can face acute water scarcity if they do not have access to water to satisfy their needs for either food security or sustainable livelihoods.

Thai farmers rely tremendously on rainfall to grow their agricultural products. Any change in rainfall, especially overall precipitation levels and distribution patterns, carries huge consequences for the farming sector. Farm holing lands for was 23.9 million ha, or $46.5 \%$ of the country, in 2017. A breakdown of where these agricultural areas were located can be summarized as follows: 5.2 million ha in the northern part, 10.2 million ha in the northeastern part, 5.0 million ha in the central part, and 3.5 million ha in the southern part (National Statistic Office 2019). Note that, of this figure, the area within irrigation was only 4.0 million ha in 2017(Royal Irrigation Department 2018).
Based on the frequency of droughts monitored over the past two decades, some experts have predicted that Thailand may now be facing a prolonged water crisis in spite of the fact that the country receives an average rainfall of $1,200 \mathrm{~mm}$ to $1,600 \mathrm{~mm}$, annually. With this amount of rainfall, the country is considered to be a water-surplus country. However, the yearly droughts have become an emerging problem in recent years, mostly because farmers have expanded agricultural activity beyond irrigated zones.

Thailand has developed into the world's largest producer and exporter of natural rubber, in alignment with the government's new policy of promoting rubber plantations. Rubber cultivation has expanded throughout many areas in Thailand. The country has produced more than three million metric tons of natural rubber annually, making it a significant source of income. One of the important changes in land use during the past few years has been the expansion of rubber tree plantations. Initially, most rubber plantations of Thailand were located in the South and the East, where there are short dry seasons and adequate rainfall throughout the year.

Since the government added a subsidy that encouraged expansion, rubber plantations have emerged in new areas such as the Northeast. Para rubber has become a major cash crop of the Northeast since then. The northeastern region 
contains the largest agricultural area, yet it is known to have unfertile areas, a long dry season, and regular encounters with water scarcity during summer months. With its large areas of plantation, water shortages can be a major constraint to agricultural production. In some of these areas, long dry periods, high temperatures, and high air vapor deficits are reported as being major constraints (Priyadarshan 2005; Rao et al. 1998).

The management of land and water are inextricably linked (Wheater 2009). With the land utilization changes in the northeastern region, it is important to understand the actual water requirement of rubber compared to those of local crops. An understanding of actual water requirements could affect the views of policy makers on the urgency at which to address water issues as well as their views on the most effective policies addressing land utilization and the economic value of crops.

Land for food production could be limited. Kastner and Nonhebel (2010) reported that in Philippines the combined effect of dietary change and population growth led again to increased land requirements for food. Thus, strong increases in yields were enabling constant land requirements for about two decades. The findings suggested that developments in land requirements for food and underlying factors are often non-linear. Caution is warranted when discussing futures of global food supply, based on assumptions of linear or continuous trends (Kastner 2010). Indonesia and Malaysia may also face similar trend due to an expansion areas of palm oil (Wicke 2011).

According to the government policy on rubber plantation promotion, this study aims to understand the consequences of this policy on water and land use change issues. The objectives of this study are 1) to estimate the water requirements of rubber plantations in Thailand associated with the expansion encouraged by Phase 3 of the Rubber Plantation Project. 2) to understand the linkage between land use changes and edible crops associated to the Rubber Plantation Project 3) to discuss and provide suggestions on water management and land use changes. Water footprint concept was applied in this study.

\section{MATERIALS AND METHODS}

\section{Rubber plantation policy}

Rubber has been a significant source of income for the country. The most important agricultural export sectors are rice, natural rubber, sugar, and cassava (FAO 2011). Rice and rubber generate the top two highest incomes from agricultural exports. From 2005 to 2008, rubber had the highest export value. As exporter of agricultural products, however, the country exploits domestic natural resources through, for example, its misuse of water resources and fertilizer in agricultural practices (Office of Agricultural Economics 2012a).

Nevertheless, the government has promoted an integration of rubber agro-forestry into the farming systems, especially in the North and Northeast. The first phase was from 2004 to 2006, and the second phase was from 2006 to 2011. The collective aim of these two consecutive projects was to increase the amount of land used for rubber plantations by 320,000 ha.

The Thai government announced plans to launch the next phase of its initiative to expand rubber plantations nationwide. The third phase is from 2011to 2013. Again, the aim is to expand the area used for rubber plantations; this time the goal is an additional 128,000 ha. Of these, a total area of 16,320 ha has been approved for participation in the Northeastern region (Fig. 1). Farmers who have their own lands (0.8-2.4 ha) and have never planted rubber trees before could now participate in the governmental program. For the third phase of the Rubber Plantation Project, the government is providing subsidized tree seedlings (18 baht/ seed or US\$0.6/seed), fertilizer, and also subsidizes of 21,870 baht/ ha or US\$729/ha for the first three years and technical expertise to help local farmers take up rubber production and move out of poverty. This includes lower tariffs resulting from the country's free trade agreements with trading partners such as China, Australia, New Zealand, and the ASEAN member states.

\section{Thailand}

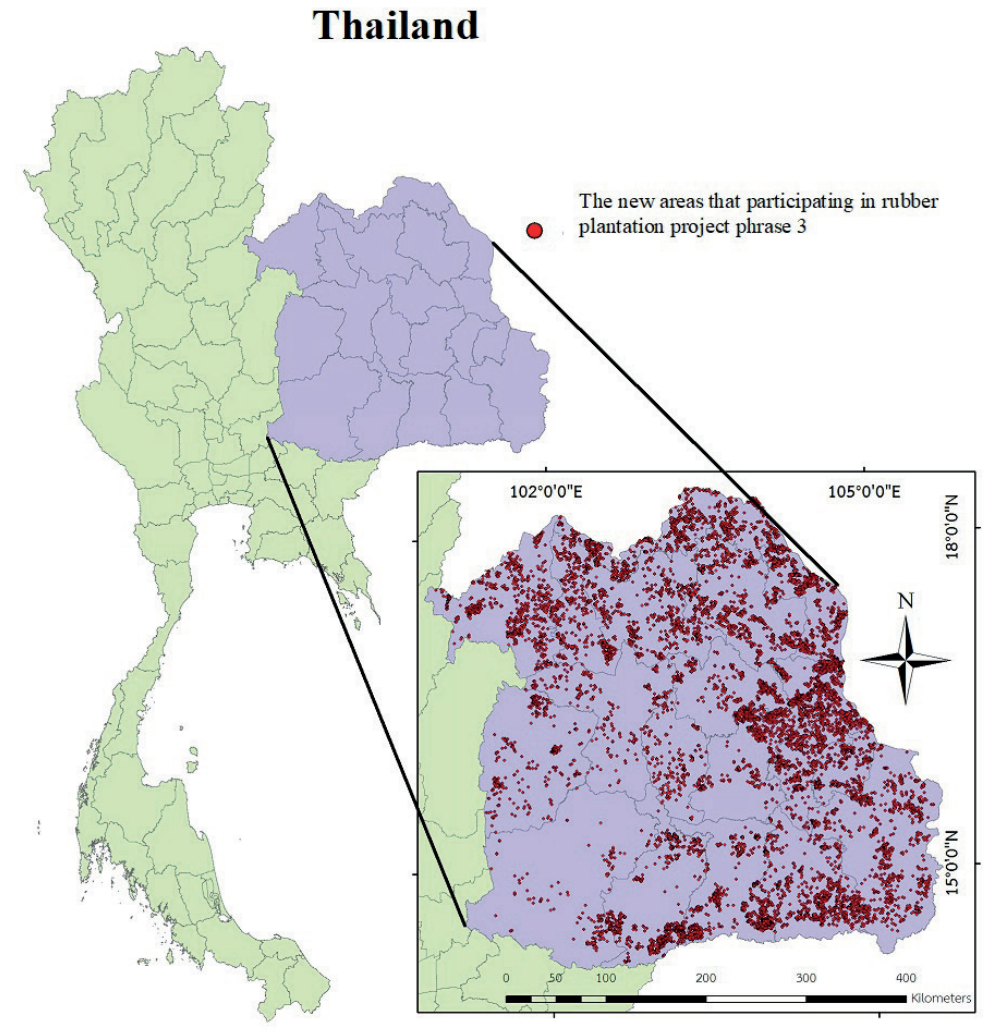

Red dots represented the farm locations participated in this project

Fig. 1. Total rubber plantation areas in the Northeastern region in alignment with rubber plantation project phase 3 


\section{North-eastern region topography}

Northeast region topography is mostly plateau at an altitude 120-400 meters above sea level. The climate in the northeast region is like a savannah which is hot and humid, alternating with the dry season with moderate rain. The rainy season starts from May to October and the summer season starts from February to May. During summer, the weather is hot and very dry because it is far from the sea. In addition, there are 3 large basins including the Mekong River, the Chi River and the Moon river. The main river basin of the region is the longest river in Thailand with a length of approximately 765 kilometers. Soil in the Northeast region is sandy soil and lack of nutrients. Underground there are rock salt, making the soil salty and dry which is not suitable for planting crops and farming. Since the northeast region is sandy soil, it cannot hold water, causing water shortages, especially during the summer. Therefore, it requires irrigation system and water storages e.g. dam or reservoir(Regional Development Policy Board 2019).

\section{Factors related to rubber growth and yield}

The rubber tree (Hevea brasiliensis) is indigenous to the tropical rainforest of the Amazon Basin near the equator, at altitudes that do not surpass $200 \mathrm{~m}$ above sea level. The suitable conditions for rubber tree growth include high temperatures of between $24-28{ }^{\circ} \mathrm{C}$ and ample annual rainfall averaging 1,500-2,500 mm (Jiang 1988; Office of Research and Development for Land Management 2005). Rao et al. (1998) identified the weekly weather conditions associated with optimum yields at 22.8 to $30.4{ }^{\circ} \mathrm{C}$, with $5.9 \mathrm{~h}$ of sunshine. Any deviation from these meteorological conditions for a period of up to 6 months had a significant impact on latex production.

All factors related to rubber growth and yields are summarized in Table 1. For rubber growth, water is an important issue because it is required for photosynthetic growth and prevents the stagnation and wilting of plant cells. During the crop growth period, particularly when negative and reproductive growth takes place simultaneously, plants need large quantities of water for photosynthesis to occur. In contrast, reproductive organs require less water (Samarasinghe 2003).

In studies by Vijayakumar (1988, 1998), tree loss was as high as $18 \%$ in the rainfed plots, while tree loss was only $3.7 \%$ in the irrigated plots. Variations in girth were also greater among rainfed plants than irrigated plants (Vijayakumar 1988; Vijayakumar 1998).
In addition, the study indicates that reductions in the photosynthetic rate and leaf area index caused by water stress significantly inhibited growth. Higher solute concentrations in latex tended to lower the photosynthetic rate. The immaturity period could thus be reduced to 6 years by irrigation (Vijayakumar 1998).

Clermont-Dauphin (2013) reported, for the first time, that soil water shortage is unexpectedly and arguably not the main cause of low growth rates. Dry air in the dry season and waterlogging in the rainy season can be even greater constraints.

With regard to yield, Rao et al. (1998) reported latex is $65-70 \%$ water and hence moisture stress influences the yield. Low latex solute potentials and sufficient available water are the conditions required for a good flow of latex. Lower yields are associated with moisture stress conditions and the withering of the tree. During a recorded drought period, for instance, a $61 \%$ lower yield than average was experienced. Of similar fluctuation was the highest yield, at $77 \%$ above the average yield. Yields of rubber trees tend to be dependent on the genotype, soil and atmospheric conditions. Most of the nutrient and water uptakes take place in the surface layers during the wet season and the same are absorbed from the deeper layers of the soil during the dry season (Rao et al. 1998). Seasonal variations of yields and yield components show that maintenance of higher soil moisture status and low vapor pressure deficits are essential to maintaining optimum water relations in rubber trees (Devakumar et al 1988; Rao et al. 1990). Regional variations in annual rubber yields are associated with the intensity and duration of moisture stress. About $40-62 \%$ of the total variations in monthly rubber production could be explained by prevailing environmental and technological factors (Daud 1989; Jiang 1988). Rainfall exceeding 9-11 mm per rainy day is not congenial to high yields owing to harvesting difficulties. Above $34 \mathrm{~mm}$ of rainfall in a day can make tapping difficult (Rao et al. 1998).

There were some differences in the root distribution patterns, yet the total root density per unit soil volume did not vary between irrigated and rainfed trees in a study by Devakumar et al. (1998). Irrigated trees intercepted nearly $88 \%$ of solar radiation during the summer and $90 \%$ in the post-monsoon season; meanwhile, rainfed trees intercepted $49 \%$ and $88 \%$ during the summer and post-monsoon season, respectively. The biomass produced by irrigated trees was significantly higher (60\%) than the biomass produced by the rainfed trees.

Table 1. Factors related to rubber tree growth and yields

\begin{tabular}{|c|c|c|}
\hline Factors & Rubber tree & References \\
\hline $\begin{array}{l}\text { Sufficient water } \\
\text { (irrigation system) }\end{array}$ & $\begin{array}{c}\text { Reduced tree loss (approximately 15\%) } \\
\text { Low variations in girth/growth rate } \\
\text { Diluted latex } \\
\text { Reduce immaturity period (approximately } 1 \text { year) } \\
\text { Increased shrub and resin yields } \\
\text { (approximately 6\%) }\end{array}$ & $\begin{array}{c}\text { (Vijayakumar 1988) } \\
\text { (Vijayakumar 1998) } \\
\text { (Rao et al. 1990) (Clermont-Dauphin 2013) } \\
\text { (Njukeng 2011) } \\
\text { (Miyamoto 1984) } \\
\text { (Ferraris 1993) }\end{array}$ \\
\hline $\begin{array}{c}\text { Meteorological parameters, } \\
\text { irradiance, ambient temperature, and } \\
\text { vapor pressure deficit }\end{array}$ & $\begin{array}{l}\text { Increased shrub and resin yields (approximately 6\%) } \\
\text { Maintenance of plant water status through their } \\
\text { effects on stomatal resistance and transpiration, } \\
\text { thereby influencing latex vessel turgor and latex } \\
\text { outputs }\end{array}$ & (Rao et al. 1990) \\
\hline $\begin{array}{l}\text { Genotype, soil moisture, } \\
\text { low vapor pressure deficit, and } \\
\text { atmospheric conditions }\end{array}$ & Seasonal variations of yields and yield components & (Rao et al. 1998) \\
\hline
\end{tabular}


Trunk volume was 57\% greater in the irrigated than that of the rainfed trees (Devakumar et al. 1998).

Meteorological parameters, irradiance, ambient temperature and vapor pressure deficits, play important roles in the maintenance of plant water status through their effects on stomatal resistance and transpiration, thereby influencing latex vessel turgor and latex outputs (Rao et al. 1990).

The results indicate that when there is a short dry period, rubber plants are not seriously affected if there is sufficient soil moisture to support nutrient uptake and evapotranspirational demand. At low soil moisture levels, the rate and duration of latex flow are reduced. Beyond a threshold, the non-availability of soil moisture in the root zone of rubber plants leads to changes in plant water relations and thus affects overall productivity.

A prolonged dry period may significantly affect yield components, such as the initial flow rate, plugging index and dry rubber content. Likewise, heavy rainfall for a prolonged period can negatively affect yields. A shorter duration of sunshine, associated with high rainfall, results in low photosynthetic efficiency. Heavy rainfall also causes nutrient loss by erosion and leaching. Cloudy weather associated with heavy rainfall may lead to disease outbreaks and also affect the photosynthetic efficiency of the plantation. When rain occurs after latex collection, an increase in the volume of latex is expected on the next day of tapping. A higher moisture status in soil may also lead to a dilution of the latex. At low soil moisture levels, the rate and duration of latex flow are dramatically reduced. These factors may be responsible for day-to-day latex yield variability (5-6\%). Also seasonal changes in rubber yield are associated with the weather and climatic conditions experienced by the plantation (Njukeng 2011).

Miyamoto (1984) reports that shrub and resin yields increased linearly with increased irrigation, while rubber contents generally decreased with increased irrigation. Resultant rubber yields were highest under the lowest stress treatment, yielding about $840 \mathrm{~kg} / \mathrm{ha}$. Thus, a dry irrigation regime may be preferred in areas with a critical water shortage if rubber production is the sole purpose of growing guayule and the economics justify low rubber yields per land area (Miyamoto 1984). In a study by Ferraris (1993), rubber yield was highest under the wet regime, mainly because of its large biomass but also because rubber contents remained relatively high (about 6\% on the average) (Ferraris 1993).

\section{Crop water requirement (CWR)}

The crop water requirement is the water needed for evapotranspiration under ideal growth conditions; it is measured from planting to harvesting. Conditions are ideal when adequate soil water is maintained by rainfall and/or irrigation so that it does not limit plant growth and crop yields. The crop water requirement is calculated by multiplying the reference crop's evapotranspiration $\left(E T_{0}\right)$ by the crop coefficient $\left(K_{c}\right): C W R=K_{c} \times E T_{0}$. It is assumed that when the CWR is fully met, the actual crop ET will be equal to the CWR (Hoekstra et al. 2009). The ET is the evapotranspiration rate from a reference surface. The reference is a hypothetical surface with extensive green grass cover possessing specific characteristics. The only factors affecting $\mathrm{ET}_{0}$ are climatic parameters. $E T_{0}$ expresses the evaporating power of the atmosphere at a specific location and time of year and does not consider crop characteristics and soil factors.
Rainfall contributes to a greater or lesser extent in satisfying the CWR, depending on the location. During the rainy season in tropical and some semi-tropical regions, a great part of a crop's water needs are covered by rainfall, while during the dry season, the major supply of water should come from irrigation. How much water is coming from rainfall and how much water should be covered by irrigation is, unfortunately, difficult to predict as rainfall varies greatly from season to season. In order to estimate the rainfall deficits for irrigation water requirements, a statistical analysis needs to be made from long-term rainfall records. In addition to the variability of rainfall from year to year, not all rain that falls is used by the crop. The intensity of rain may be such that part of the rainfall is lost due to surface runoff or due to deep percolation below the root zone. In order to determine the part of the rainfall that effectively contributes to the CWR, a number of definitions are first given. It is then subsequently explained how the different rainfall values can be calculated and how they are incorporated in the CWR calculations.

\section{Water footprint (WF)}

The WF of a product (commodity, good or service) is defined as the volume of freshwater that is used for its production. The WF of crop cultivation can be estimated following the 2011 WF assessment manual of Hoekstra et al. (2009). Total water use is a summation of the green water, blue water, and gray water. The green WF refers to rainwater that evaporates during the production process. This is particularly relevant for crop growth. The blue WF refers to surface water and groundwater used for irrigation that evaporate during production process. The gray water is the volume of polluted water as well as the volume of dilution water that is discharged during the production process; it is defined as the amount of water needed to dilute pollutants emitted to natural water systems during the production process to the extent that the quality of the ambient water remains within agreed upon water quality standards. Green and blue water can be estimated by CROPWATS. The grey component of crop or tree growth (WFproc,grey, $\mathrm{m}^{3} /$ ton) is calculated as the chemical application rate per hectare (AR, kg/ha) times the leaching fraction (a) divided by the maximum acceptable concentration $\left(\mathrm{cmax}, \mathrm{kg} / \mathrm{m}^{3}\right)$ minus the natural concentration for the pollutant considered $\left(\mathrm{cnat}, \mathrm{kg} / \mathrm{m}^{3}\right.$ ) and then divided by the crop yield ( $\mathrm{Y}$, ton/ha).

$$
W F_{\text {proc.gray }}=\frac{(\alpha \times A R) /(\text { Cmax }- \text { Cnat })}{Y}
$$

The pollutants generally consist of fertilizers (e.g., nitrogen, phosphorus), pesticides and insecticides. One has to consider only the "waste flow" to freshwater bodies, which is generally a fraction of the total application of fertilizers or pesticides to the field. One needs to account for only the most critical pollutant; that is, the pollutant yielding the highest water volume using the above calculation.

\section{CWR, green, and blue water estimation method}

The CROPWAT 8.0 program can be applied to estimate green and blue water of crop and help with the design and management of irrigation schemes, taking the user, with the help of an actual data set, through the different steps required to calculate evapotranspiration, crop water requirements, scheme water supply and 
irrigation scheduling. Since the cultivation of most crops relies on rainfed systems, in this study, blue water represents the additional water needed from irrigation system when rainfall is insufficient. The model requires the types of input summarized in Table 2.

The FAO Penman-Monteith equations were used to produce the $\mathrm{ET}_{0}$ data in Table $\mathrm{A} 1$ reported by the Royal Irrigation Department (2011). ET was calculated with weather data from 120 weather stations within 64 provinces from 1981 to 2010. ET data was reported by the Royal Irrigation Department (2011).

The rainfall data comprises the average rainfall values from 2002 to 2012 (10 years) provided by the Thai Meteorological Department. The crop coefficient $\left(K_{c}\right)$ varies over the length of a growing period. The $K_{c}-P e n m a n$ Monteith value of crops were obtained from the Royal Irrigation Department (Irrigation Water Management Research Group) and are summarized in Table 3. The $\mathrm{K}_{\mathrm{c}}$ was divided into three stages: the initial, mid-season, and final stages. The lengths of the individual growth stages were also used as input data for the program. For example, the growth stages for cassava total 360 days; for corn, 99 days; and for rubber, 25 years. The rooting depth of rubber ranges from 1.5 to $2 \mathrm{~m}$ for primary roots and secondary roots, while lateral roots can spread as far as 20 meters (Office of Research and Development for Land Management 2005). Critical depletion occurs at about $40 \%$ of the total available soil moisture (Homyarnyen 2007). The yield response factor represents relative yield that decreases in relative to evapotranspiration deficit. The yield response factors of rubber were calculated and were in the range of $0.33-0.49$.

\section{Gray water calculation method}

According to gray water calculation equation, in this study, $a$ is the amount of nitrogen leaching using the rate of 10\% (Nevison). According to interview with approximately 300 farmers, the nitrogen (chemical fertilizer) application rate per hectare (AR) is $118 \mathrm{~kg}-\mathrm{N} / \mathrm{ha} / \mathrm{yr}$ for rubber, $98 \mathrm{~kg}-\mathrm{N} /$ ha/yr for sugarcane, $98 \mathrm{~kg}-\mathrm{N} / \mathrm{ha} / \mathrm{yr}$ for corn, $58 \mathrm{~kg}-\mathrm{N} / \mathrm{ha} /$ $\mathrm{yr}$ for rice, and $80 \mathrm{~kg}-\mathrm{N} / \mathrm{ha} / \mathrm{yr}$ for cassava. These rates were obtained from interviews with farmers. The $C \max$ is the nitrogen standard concentration $0.005 \mathrm{~kg} / \mathrm{m}^{3}, \mathrm{C}$ nat $=0$, and $Y$ is the average yield per area (Office of Agricultural Economics 2012b). For the water footprint calculation, the average time for planting a rubber tree is 25 years. The tree can be tapped after year 7 . Then total water footprint of a rubber tree is its 25 years of growth divided by its 18 years of yields. The sum of the blue, green, and gray water is called the water footprint of crop cultivation (for use in a hypothetical situation or an actual crop water requirement). The functional unit is the actual crop water requirement $(\mathrm{L})$ per yield $(\mathrm{kg})$.

\section{Table 2. Input parameters for CROPWAT}

\begin{tabular}{|c|c|c|}
\hline Input & Parameters & Data sources \\
\hline Weather & $\begin{array}{l}\text { - Evapotranspiration (ET0) } \\
\text { - Rainfall data }\end{array}$ & $\begin{array}{l}\text { - The Royal Irrigation Department } \\
\text { - The Thai Meteorological Department }\end{array}$ \\
\hline Crop data & $\begin{array}{l}\text { - Crop coefficient (Kc) } \\
\text { - Growing stage } \\
\text { - Rooting depth } \\
\text { - Critical depletion } \\
\text { - Yield response factor }\end{array}$ & $\begin{array}{c}\text { - FAO and } \text { Ministry of Agriculture } \\
\text { - Literature } \\
\text { - Literature } \\
\text { - Literature } \\
\text { - Calculations }\end{array}$ \\
\hline Soil data & $\begin{array}{c}\text { - Total available soil moisture } \\
\text { - Max rain infiltration rate } \\
\text { - Rooting depth }\end{array}$ & $\begin{array}{l}\text { - Literature } \\
\text { - Laboratory and literature } \\
\text { - Literature }\end{array}$ \\
\hline
\end{tabular}

Table 3. $\mathrm{K}_{\mathrm{c}}$-Penman Monteith values of crops

\begin{tabular}{|c|c|c|c|c|c|c|}
\hline Month & Sugarcane & Cassava & Rubber & Week & Rice & Corn \\
\hline 1 & 0.65 & 0.3 & 0.65 & 1 & 1.03 & 0.63 \\
\hline 2 & 0.86 & 0.3 & 0.86 & 2 & 1.07 & 0.72 \\
\hline 3 & 1.13 & 0.3 & 1.13 & 3 & 1.12 & 0.86 \\
\hline 4 & 1.35 & 0.8 & 1.35 & 4 & 1.29 & 1.13 \\
\hline 5 & 1.56 & 1.1 & 1.56 & 5 & 1.38 & 1.35 \\
\hline 6 & 1.29 & 1.1 & 1.29 & 6 & 1.45 & 1.52 \\
\hline 7 & 1.20 & 1.1 & 1.20 & 7 & 1.50 & 1.61 \\
\hline 8 & 0.93 & 0.5 & 0.93 & 8 & 1.48 & 1.63 \\
\hline 9 & 0.63 & 0.5 & 0.63 & 9 & 1.42 & 1.58 \\
\hline 10 & 0.52 & 0.5 & 0.52 & 10 & 1.34 & 1.50 \\
\hline 11 & - & 0.5 & 0.52 & 11 & 1.23 & 1.38 \\
\hline 12 & - & 0.5 & 0.52 & 12 & 0.94 & 1.15 \\
\hline 13 & - & - & - & 13 & 0.86 & 0.90 \\
\hline 14 & - & - & - & 14 & - & 0.67 \\
\hline
\end{tabular}




\section{RESULTS}

\section{Water consumption}

The results show that rubber plantations require larger amounts of water than other crops (e.g., sugarcane, rice and corn). On average, the water requirement for rubber is $14,221 \mathrm{~m}^{3} / \mathrm{ha} /$ year (41\% blue water, BW and $59 \%$ green water, GW ); sugarcane, $12,177 \mathrm{~m}^{3} / \mathrm{ha}$ /year (36\% BW and $64 \% \mathrm{GW})$; cassava, $9668 \mathrm{~m}^{3} / \mathrm{ha}$ /year (52\% BW and 48\% GW); rice, $5220 \mathrm{~m}^{3} / \mathrm{ha} /$ year (-27\% BW and $73 \% \mathrm{GW}$ ); and corn for animal feed, $4417 \mathrm{~m}^{3} / \mathrm{ha} /$ year (46\% BW and 54\% GW ) (Fig. 2 (a)). This implies that rainfall alone is not enough, especially during the dry season. One exception is rice, which we assumed was planted in a semi-flooded area. Green water counts for approximately 59\% of the actual rubber crop water requirement, which is comparable to sugarcane at $64 \%$, cassava at $48 \%$, and corn at $54 \%$. Thus, irrigation systems must be utilized during certain months.

The water footprint of each crop was estimated. The study boundary is only in the field or plantation process only. The water footprint for rubber is 13,067-17,257 L/kg yield; for sugarcane, it is 188-209 L/kg yield; for cassava, it is 512-625 $\mathrm{L} / \mathrm{kg}$ yield; for corn, it is 1,413-1,877 L/kg yield; and for rice, it is 2,716-3,366 L/kg yield (Fig. 2 (b)). Rubber produced the most gray water (1,600 L/kg yield), followed by rice (550 L/ $\mathrm{kg}$ yield), corn (500 L/kg yield), cassava ( $80 \mathrm{~L} / \mathrm{kg}$ yield), and sugarcane (30 L/kg yield). If farmers increased their rubber yields, the amount of gray water would lessen.

The mean annual rainfall in the northeastern region from 2001-2010 was 1,530 mm, and the rainfall was most concentrated between the months of June and September. Plants, however, experienced stress conditions from midOctober to April. Figure 3, results of the CROPWATS model, showed rubber's water requirement to meet optimal condition during each month of different types of northeastern soil. The green bars represent effective rainfall and the blue bars represent the additional irrigation water requirement. From the Figure 3, there are not much different variation of water requirement between different types of soil due to their soil characteristics in the region that cannot hold water. The region experienced an average water deficit of $580 \mathrm{~mm}$ during the summer months. Drought survival is important in the northern part of Thailand, where long dry periods can threaten tree survival the first year after planting, as tree growth is more easily affected in the early stage of development during a drought period (Sangsing 2004).

\section{Land use changes and local water requirements}

According to Phase 3 of the Rubber Plantation Project, the quota for the Northeast region is 80,000 ha. Of these, a total area of 16,320 ha was approved for participation. Only 4,456 ha (or $27 \%$ ) of the total approved area has actually

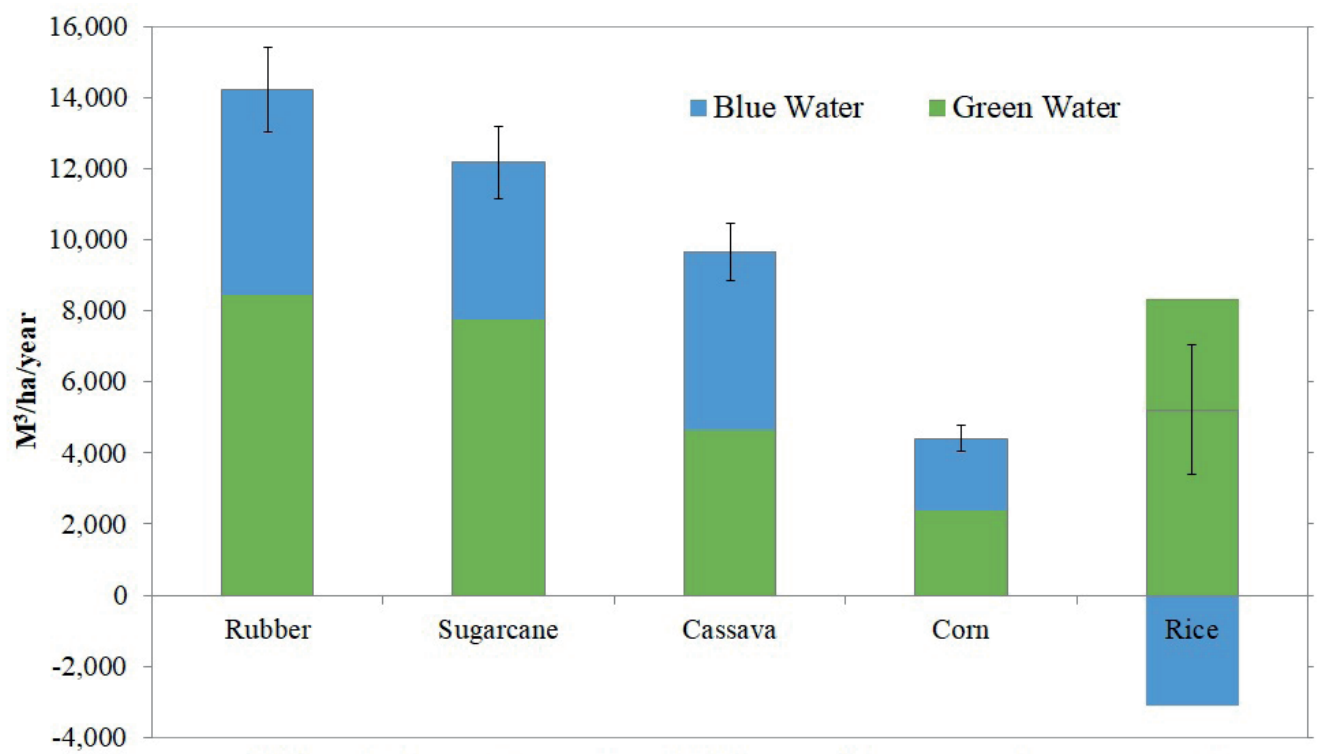

(a) The actual crop water requirement is the sum of blue water and green water volumes

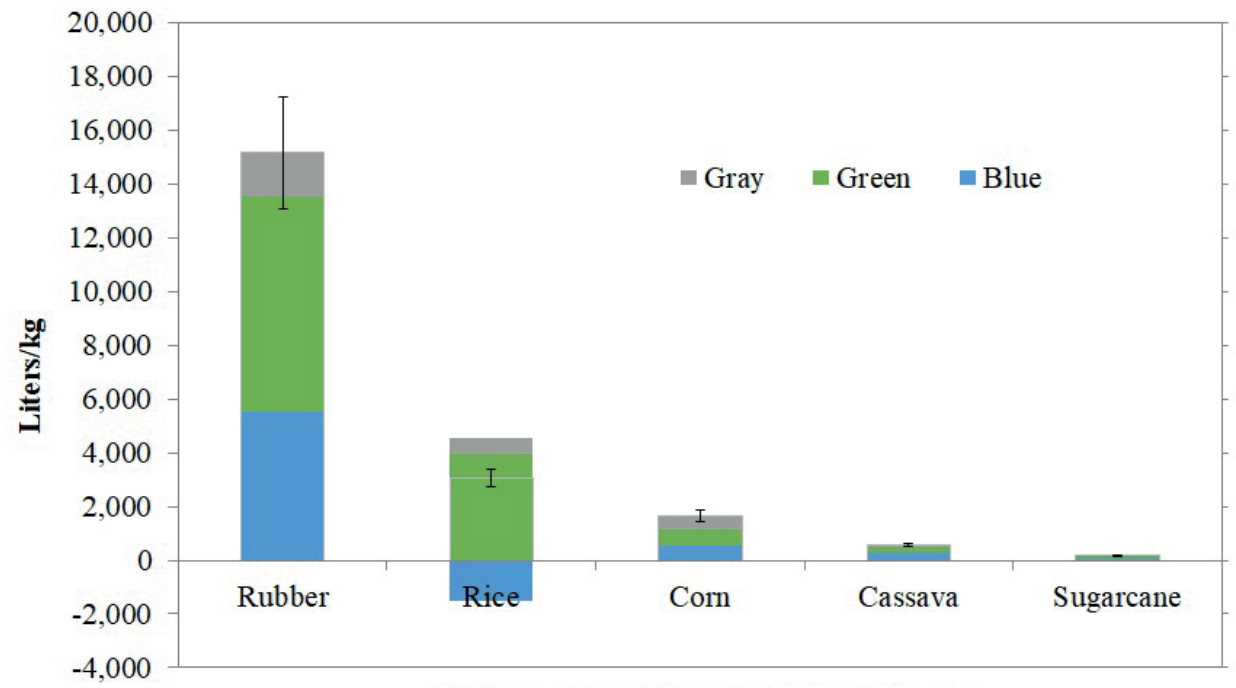

(b) Green, blue, and gray water of each crop

Fig. 2. Crop water requirements in the northeastern part of Thailand 
been used for planting rubber trees, while the rest $(11,908$ ha) have not yet been used for planting rubber. This is partly due to the fact that the government terminated a subsidy policy on Jan. 4, 2013 - also due to the rapid drop in rubber price - Of the 11,908 ha, 7,979 ha is home to rice paddies, cassava, sugarcane, and corn fields. The rest of 3,929 ha is destroyed forestland and grassland.

To maintain the status quo, in the new rubber plantation areas $(4,456 \mathrm{ha})$, the actual water requirement for planting rubber is 60-65 million $\mathrm{m}^{3} / \mathrm{yr}$, more than double the regular water requirement for edible crops of around 27-29 million $\mathrm{m}^{3} / \mathrm{yr}$. If all the approved areas in the project (100\%) were converted to rubber tree plantations, the total rubber vield $\mathrm{mm}$ would be $20.6 \mathrm{M} \mathrm{kg}$ and the additional water requirement in the region would be 53-57 million $\mathrm{m}^{3} / \mathrm{yr}$ (Table 4). Expected rubber yield, if adequate irrigation is provided, could increase rubber yield at a rough estimate of $6 \%$ or $1.2 \mathrm{M} \mathrm{kg}$. However, this large amount of water cannot be acquired unless the support from the government to promote irrigation systems and individual or village reservoirs. Otherwise, this can lead to policy failure in a long run.

Thailand is also an exporter of food and agricultural products. A change from the planting of edible crops to rubber plantations does not affect the amount of food available for domestic consumption since Thailand exports more crops than it consumes domestically, with the

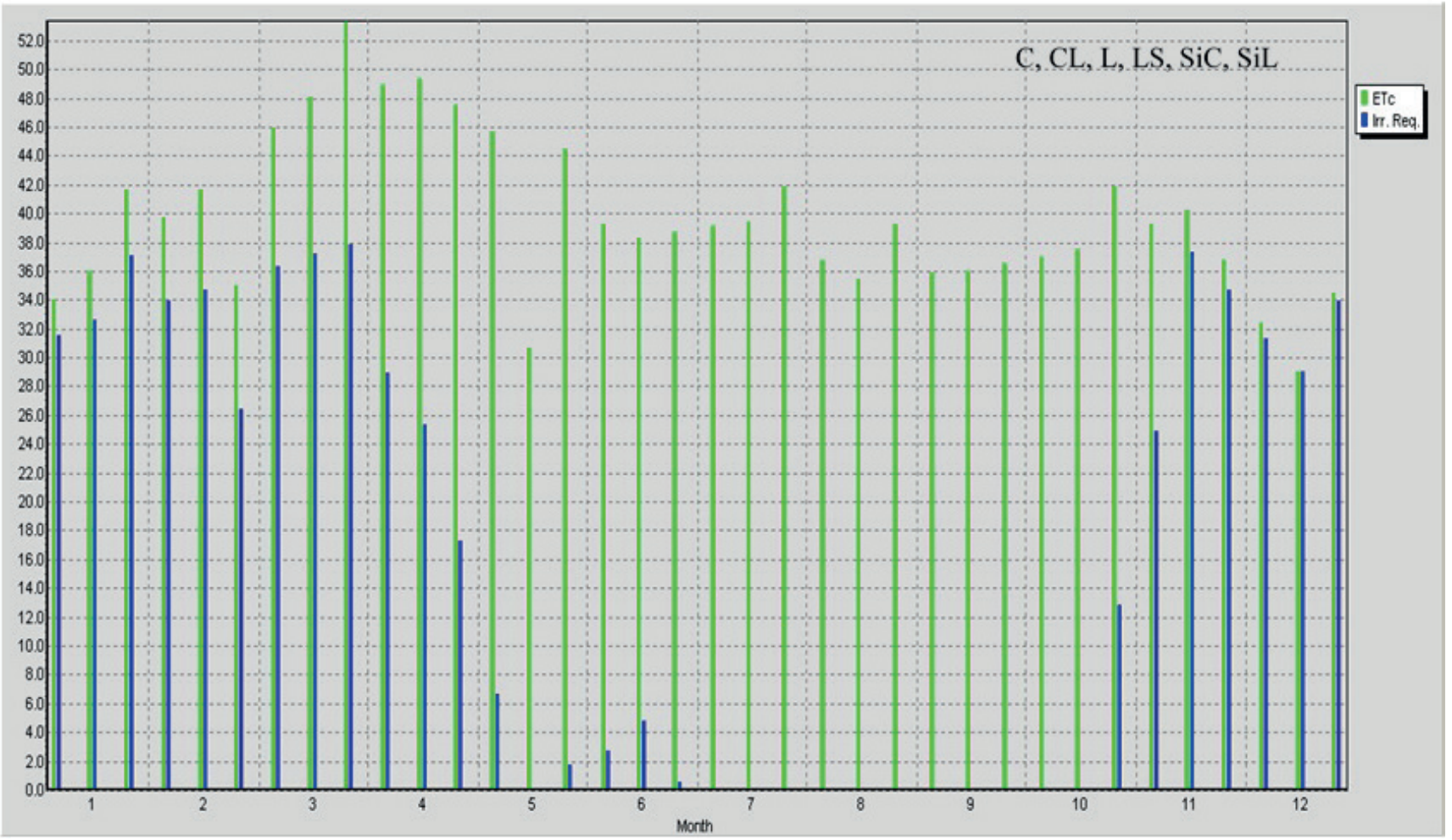

Fig. 3. Rubber's water requirement during each month (the green bars represent effective rainfall and the blue bars represent the additional irrigation water requirement needed to meet the optimal condition) of Clay (C), Clay Loam (CL) , Loam (L), Sandy Loam (LS), Silty Clay (SiC), Silty Loam (SiL) (y-axis is month and $x$-axis is $\mathrm{mm}$ )

Table 4. Land use and water requirements of the agricultural products subject to the rubber plantation policy

\begin{tabular}{|c|c|c|c|c|c|c|c|c|c|c|}
\hline & \multicolumn{4}{|c|}{ Area (ha) } & \multicolumn{2}{|c|}{ Water requirement $\left(\mathrm{M} \mathrm{m}^{3}\right)$} & \multicolumn{3}{c|}{ Products (M kg) } \\
\cline { 2 - 13 } & $\begin{array}{c}\text { Rubber } \\
\text { plantation }\end{array}$ & $\begin{array}{c}\text { Incremental } \\
\text { Rubber plantation }\end{array}$ & Mix crop & Rubber & Mix crop & $\begin{array}{c}\text { Incremental } \\
\text { water }\end{array}$ & Rice & Corn & Cassava & Rubber \\
\hline Status quo & 4,456 & - & 7,979 & $61.2-65.9$ & $56.7-60.7$ & - & 16.9 & 10.3 & 24.0 & 7.4 \\
\hline $10 \%$ & 5,254 & 798 & 7,181 & $72.2-77.7$ & $96.2-104.0$ & $50.4-55.1$ & 14.5 & 8.9 & 20.6 & 8.7 \\
\hline $20 \%$ & 6,052 & 1,596 & 6,383 & $83.1-89.5$ & $85.5-92.4$ & $50.7-55.3$ & 9.8 & 6.0 & 14.0 & 10.0 \\
\hline $30 \%$ & 6,850 & 2,394 & 5,585 & $94.1-101.4$ & $74.8-80.9$ & $50.9-55.6$ & 6.9 & 4.2 & 9.8 & 11.3 \\
\hline $40 \%$ & 7,647 & 3,192 & 4,787 & $105.1-113.2$ & $64.1-69.3$ & $51.2-55.9$ & 4.8 & 3.0 & 6.8 & 12.7 \\
\hline $50 \%$ & 8,445 & 3,990 & 3,990 & $116.0-125$ & $53.4-57.8$ & $51.5-56.1$ & 3.9 & 2.4 & 5.6 & 14.0 \\
\hline $60 \%$ & 9,243 & 4,787 & 3,192 & $127.0-136.8$ & $42.7-46.2$ & $51.8-56.4$ & 3.0 & 1.8 & 4.3 & 15.3 \\
\hline $70 \%$ & 10,041 & 5,585 & 2,394 & $138.0-148.6$ & $32.1-34.7$ & $52.0-56.6$ & 1.2 & 0.8 & 1.7 & 16.6 \\
\hline $80 \%$ & 10,839 & 6,383 & 1,596 & $148.9-160.4$ & $21.4-23.1$ & $52.3-56.9$ & 0.8 & 0.5 & 1.2 & 17.9 \\
\hline $90 \%$ & 11,637 & 7,181 & 798 & $159.9-172.2$ & $10.7-11.6$ & $52.6-57.1$ & 0.8 & 0.5 & 1.1 & 19.3 \\
\hline $100 \%$ & 12,435 & 7,979 & - & $170.8-184.0$ & - & $52.9-57.4$ & - & - & - & 20.6 \\
\hline
\end{tabular}


exception of rice. This should not pose a problem. In 2012, for example, Thailand exported 6,734 M kg of rice (Office of Agricultural Economics 2012b). The production of rice in the areas under Phase 3 development, however, was only $17 \mathrm{M} \mathrm{kg}$, accounting less than $1 \%$ of the total amount of rice exported. When combine all the 3 phase projects together with the total areas of rubber plantation of 448,000 ha, total rubber yield would increase to $742 \mathrm{M} \mathrm{kg}$ and rice, corn, and cassava would disappear about $1613 \mathrm{M} \mathrm{kg} \mathrm{(24 \%} \mathrm{of} \mathrm{the} \mathrm{total} \mathrm{amount} \mathrm{of} \mathrm{rice}$ exported in 2012), 7837 M kg, 8926 M kg, respectively. When standardize crop water requirement with value gain from export, every thousand US dollar gain from rubber requires 547-629 $\mathrm{m}^{3}$ of water (Mangmeechai 2013).

\section{Crop per drop}

The total volume of water used globally for crop production is $6390 \mathrm{Gm}^{3} / \mathrm{yr}$ at field level. Rice is responsible for the largest share of the total water volume used for global crop production. It consumes about $1359 \mathrm{Gm}^{3} / \mathrm{yr}$, which is about $21 \%$ of the total volume of water used for crop production at field level. The second largest water consumer is wheat (12\%) (Hoeskstra 2007).

Given the importance of agriculture to Thailand, production efficiency needs to be a priority. When comparing the water requirements for growing crops in the Northeastern region with the world averages reported by (Hoeskstra 2007). The water per yield averages of Thai rice and maize were higher than their corresponding world averages (Table 5).

Based on the Hoeskstra (2007) report, the four most important direct factors explaining high water footprints are (1) gross national income, (2) a water-intensive consumption pattern, (3) climate, and (4) water-inefficient agricultural practices. The third and fourth factors are clear explanations for the high water consumption of agriculture in Thailand. With regard to climate, the regions with high evaporative demands have relatively large water requirements per unit of crop production. A fourth factor that can explain high water footprints is the use of agricultural practices that utilize water inefficiently, which means that water productivity in terms of output per drop of water is relatively low. This factor partly explains the high water footprints of countries such as Thailand, Cambodia, Turkmenistan, Sudan, Mali and Nigeria
(Hoeskstra 2007). Yield is an indicator of the efficiency of an agricultural practice. For example, the yield for the major Thai export, rice, was lower than the world average: the world average rice yield was 4.3 tons/ha, while the Thai rice yield was 2.9 tons/ha (Office of Agricultural Economics 2012b). Thailand's cassava yield (22.7 tons/ha) was higher than the world average (12.5 tons/ha). The sugarcane yield of Thailand (69.3 tons/ha) was slightly lower than the world average (70.2 tons/ha). The Thai rubber yield was 1.7 tons/ ha, slightly greater than the world average of 1.2 tons/ha (Office of Agricultural Economics 2012b).

In order to increase its crop-per-drop efficiency in the face of increased water shortage issues, Thailand needs to develop irrigation systems that enhance crop yields and improve the efficiency of water applications, rather than endlessly seeking new supplies. More storage and decentralized micro-irrigation are necessary to save water in times of water surplus for use in times of water shortage (Bouwer 2000; FAO 2002; Rijsberman 2006; Sosothikul 2010). All of these activities must be implemented under the framework of river-basin management to ensure coherent planning, policy-making with wide public participation, and the implementation of effective water-resource, landuse and flood management measures (Editorial 2007). The government should move toward on promoting rubber plantation policy since it provides higher revenue for farmers, in the meantime, irrigation systems should be developed to improve crop per drop and land use efficiency.

\section{DISCUSSION}

The Thai government launched Phase 3 of its Rubber Plantation Project in 2011. The project aims to expand the total area of new plantations to 128,000 ha, from 2011 to 2013. The northeastern region contains the largest areas for new rubber plantation areas, yet it is known to have unfertile areas, a long dry season, and regular encounters with water scarcity during summer months. This objective leads to research questions as to how the policy affects land and water use in the country. The results of this study can thus be used to introduce recommendations on water management for more sustainable rubber plantations in the area and maximized land use.

Table 5. Average virtual water content of some selected products for a number of selected countries ( $\mathrm{m}^{3} /$ ton)

\begin{tabular}{|c|c|c|c|}
\hline Country & Rice (paddy) & Maize & Sugar cane \\
\hline USA & 1275 & 801 & 103 \\
\hline China & 1321 & 1937 & 159 \\
\hline India & 2850 & 1397 & 174 \\
\hline Russia & 2401 & 1285 & 141 \\
\hline Indonesia & 2150 & 744 & 155 \\
\hline Australia & 1022 & 1180 & 120 \\
\hline Brazil & 3082 & 1493 & 171 \\
\hline Japan & 1221 & 1744 & - \\
\hline Mexico & 2182 & 530 & - \\
\hline Italy & 1679 & 408 & 175 \\
\hline Netherlands & - & 909 & 171 \\
\hline World average & 2291 & 1143 & \\
\hline Thailand & 2488 & & \\
\hline
\end{tabular}


This study shows that the water requirement of rubber trees is higher than that of other local crops (e.g., rice, cassava, sugarcane, and corn). On average, the water requirement for rubber is $14,221 \mathrm{~m}^{3} / \mathrm{ha}$ /year (41\% blue water, BW and $59 \%$ green water, GW); sugarcane, $12,177 \mathrm{~m}^{3} / \mathrm{ha} /$ year (36\% BW and 64\% GW); cassava, $9668 \mathrm{~m}^{3} / \mathrm{ha}$ /year (52\% BW and 48\% GW); rice, $5220 \mathrm{~m}^{3} / \mathrm{ha} /$ year (-27\% BW and 73\% GW ); and corn for animal feed, $4417 \mathrm{~m}^{3} / \mathrm{ha} /$ year (46\% BW and 54\% GW). In the study, agricultural green water refers to water from effective rainfall, while blue water refers to the additional water supplied to meet optimal growing conditions. This implies that the rainfall, especially during the dry season, cannot sufficiently meet the actual crop water requirements. Thus irrigation systems must be utilized in certain months. The results show that during the dry months, Nov. to April, water is insufficient; meanwhile, water is provided in excess from May to Oct. Thus, irrigation systems must be utilized during certain months. The land use changes from the cultivation of edible crops to rubber do not threaten the amount of food available for domestic consumption since Thailand generally exports more of its crops than it consumes.

Regarding to the verification and uncertainty of the data, this study used primary data and secondary data from government reports. The methodology and data collection for primary data followed crop water requirement manual which has been used worldwide. The CROPWAT model was verified by comparing the estimation of crop water requirement from equation and the CROPWAT program. The results showed that the difference between the two methods did not exceed more than 10\% (Fig. 4).

\section{CONCLUSIONS}

The Thai government launched Phase 3 of its Rubber Plantation Project in 2011 aiming to expand the total area of new plantations to 128,000 ha. This policy attempts to create a more stable income for famers without concerning other aspects e.g. climate, geographic, and water resources suitable for rubber plantation, fluctuation of rubber market price, land use changes, and food security etc.

By taking these aspects into account, the findings of this study suggests the government and local government to provide a better plan for the rubber plantation project by considering crop water requirements suitable for each region. Irrigation system or individual or community reservoir should be planed. In addition, education provided to all farmers on increasing crop-per-drop efficiency is necessary.

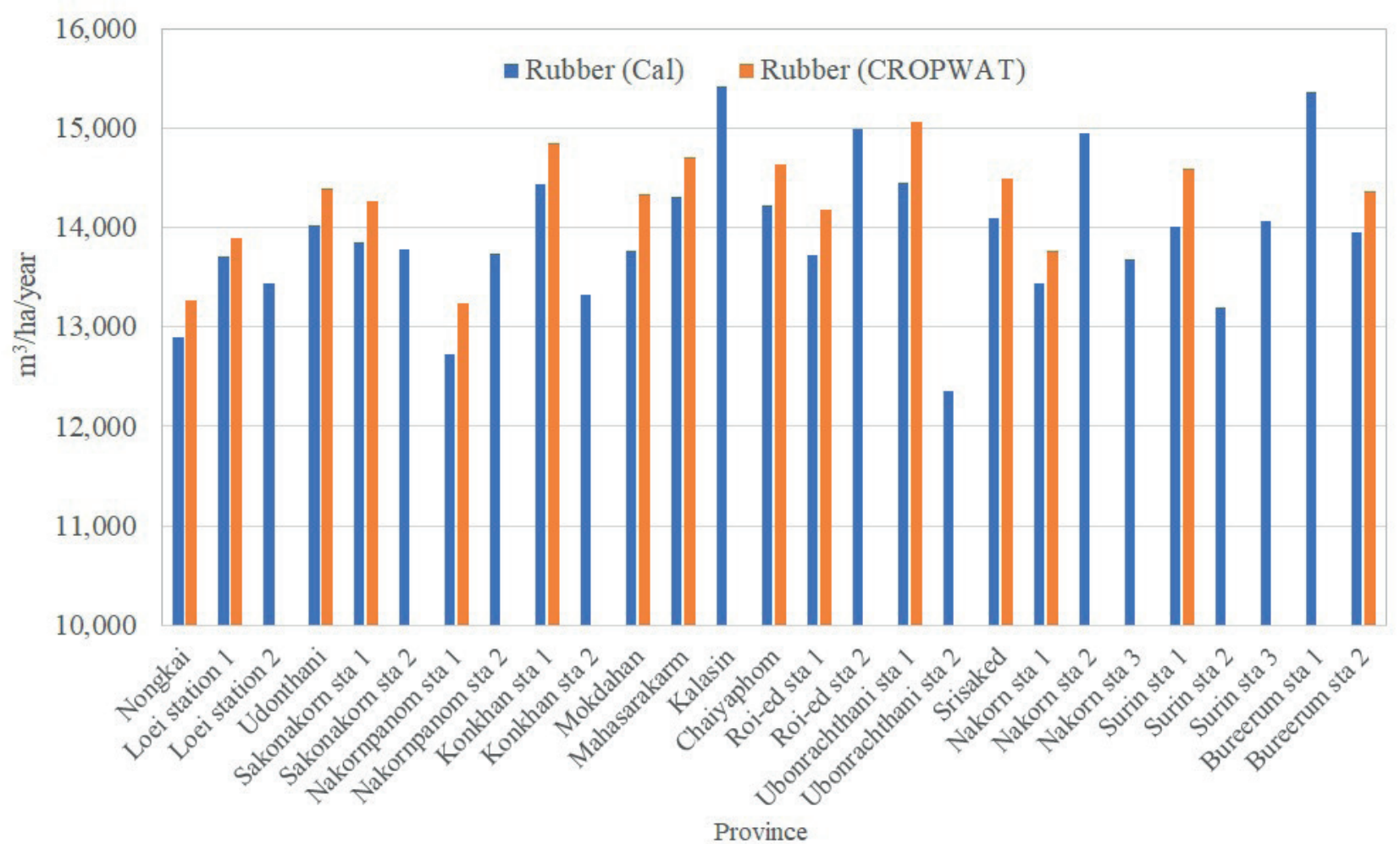

Fig. 4. Rubber water consumption from calculations and from the CROPWAT program 


\section{REFERENCES}

Bouwer H. (2000). Integrated water management:emerging issues and challenges. Agricultural Water Management, 45, $217-228$. Clermont-Dauphin C., Suvannang N., Hammecker C., Cheylan V., Pongwichian P. and Do F. (2013). Unexpected absence of control of rubber tree growth by soil water shortage in dry subhumid climate. Agronomy for Sustainable Development, 33, 531-538.

Daud N., Nayagam N., and Veramuthoo P. (1989). Effects of selected environmental and technological factors on rubber production. A case study of RRIM economic laboratory. Journal of Natural Rubber Resource, 4(1), 66-74.

Devakumar A., Rao G., Rajgopal R., Rao P., George M., Vijayakumar K. and Sethuraj M. (1988). Studies on soil-plant-atmosphere system in Helea: II. Seasonal effects on water relations and yield. Indian Journal of Natural Rubber Resource, 1(2), 45-60.

Devakumar A., Prakash P., Sathik M. and Jacob L. (1998). Drought alters the canopy architecture and micro-climate of Hevea brasiliensis trees. Trees, 13, 161-167.

Editorial. (2007). Solving Thailand's water crisis: A comprehensive approach is needed in resource management to effectively deal with flood and drought problems. [online] The Nation. Available at: www.nationmultimedia.com/2007/03/11/opinion/opinion_30028990.php [Accessed 30 Mar. 2015].

FAO. (2002). Crops and Drops: Making the best Use of Water for Agriculture. [online] Available at: www.fao.org/3/Y3918E/Y3918E00.htm [Accessed 1 Mar. 2015]. 2015].

FAO. (2011). Thailand and FAO Achievements and success stories. [online] Available at: www.fao.org/3/a-at017e.pdf [Accessed 1 Apr.

Ferraris R. (1993). Effect of plant density on yield and rubber accumulation in guayule (Parthenium argentatum) in south-eastern Queensland. Journal of Experimental Agriculture, 33(1), 71-82.

Hoeskstra Y. and Chapagain K. (2007). Water footprints of nations: Water use by people as a function of their consumption pattern. Water Resources Management, 21, 35-48.

Homyarnyen K. (2007). Water irrigation for growing asparagus in Nakorn Pratom Province. Bangkok: Ministry of Agriculture and Cooperatives.

Irrigation Water Management Research Group. Crop Coefficient (Kc) 40 crop types. [online] Available at:water.rid.go.th/hwm/cropwater/ CWRdata/Kc/kc_th.pdf [Accessed 25 Dec. 2014].

Jiang A. (1988). Climate and natural production of rubber (Hevea brasiliensis) in Xishuangbanna, southern part of Yunnan province, China. International Journal of Biometeorology, 32, 280-282.

Kastner T. and Nonhebel S. (2010). Changes in land requirements for food in the Philippines: A historical analysis. Land Use Policy, 27, 853-863.

Mangmeechai A. (2013). Environmental externalities in relation to agricultural sector in Thailand with tradelinked analysis. Environment, Development and Sustainability, DOI: 10.1007/s10668-013-9509-2.

Miyamoto S., David J. and Piela K. (1984). Water use, growth and rubber yields of four Guayule selections as related to Irrigation regimes. Irrigation Science, 5, 95-103.

National Statistic Office. (2019). Statistics of Land Utilization by Region and Province Year: 2008-2017. [online] Available at: www.statbbi. nso.go.th/staticreport/page/sector/en/11.aspx [Accessed 5 Feb. 2015].

Nevison C. Good Practice Guidance and Uncertainty Management in National Greenhouse Gas Inventories: Indirect N2O Emissions from Agriculture.Water Evaluation and Planning. Yield Response to Water Shortage. [online] Available at: www.weap21.org/webhelp/Mabia_ Alg_Yield.htm [Accessed 20 Feb. 2015].

Njukeng J., Muenyi P., Ngane B. and Ehabe E. (2011). Ethephon Stimulation and Yield Response of Some Hevea Clones in the Humid Forests of SouthWest Cameroon. International Journal of Agronomy. [online]. Available at: DOl: 10.1155/2011/257340 [Accessed 2 Feb. 2015]. Office of Agricultural Economics. (2012a). Agricultural Situation and Trend 2012. [online] Available at: www.oae.go.th/assets/portals/1/ files/ebook/trends2555.pdf [Accessed 25 Feb. 2015].

Office of Agricultural Economics. (2012b). Agricultural Statistics of Thailand. Bangkok: Ministry of Agriculture.

Office of Research and Development for Land Management. (2005). Rubber. Bangkok: Land Development Department.

Priyadarshan P., Hoa T., Huasun H. and Goncalves P. (2005). Yielding Potential of Rubber (Hevea brasiliensis) in Sub-Optimal Environments. Journal of Crop Improvement, 14(1-2), 221-247.

Rao G., Rao P., Rajagopal R., Devakumar A., Vijayakumar K. and Sethuraj M. (1990). Influence of soil, plant and meteorological factors on water relations and yield in Hevea brasiliensis. International Journal of Biometeorol, 34(3), 175-180.

Rao P., Saraswathyamma C. and Sethuraj M. (1998). Studies on the relationship between yield and meteorological parameters of para rubber tree (Hevea brasiliensis). Agricultural and forest meteorology, 90, 235-245.

Regional Development Policy Board. (2019). Northeast Development Plan in the 12th National Economic and Social Development Plan

(2017-2021). [online] Available at: www.nesdb.go.th/ewt_dl_link.php?nid=7526\&filename=index [Accessed 1 Mar. 2015].

Rijsberman F. (2006). Water scarcity: Fact or fiction? Agricultural Water Management, 80, 5-22.

Royal Irrigation Department. (2018). Annual Report 2018. [online] Available at: www1.rid.go.th/main/_data/annual-conclusion/RIDAnnual/RID_Annual_2018.pdf [Accessed 25 Jan. 2015].

Samarasinghe B. (2003). Growth and yields of Sri Lanha's major crops interpreted from public domain satellites. Agricultural Water Management, 58, 145-157.

Sangsing K., Kasemsap P., Thanisawanyangkura S., Sangkhasila K., Gohet E., Thaler P. and Cochard H. (2004). Xylem embolism and stomatal regulation in two rubber clones (Hevea brasiliensis Muell. Arg.). Trees, 18, 109-114.

Sosothikul P. (2010). The water shortage: crisis of opportunity? [online] Bangkok post. Available at: www.eng.moac.go.th/ewt_news. php?nid=58\&filename=index [Accessed 25 Feb. 2015].

Vijayakumar R. (1988). Physiology of drought tolerance of Helea. Compte-Rendu du Colloque Exploitation Physiologic et Amelioration de l'Helea, 269-281.

Vijayakumar K., Dey S., Chandrasekhar R. and Austin D. (1998). Irrigation requirement of rubber trees (Hevea brasiliensis) in the subhumid tropics. Agricultural Water Management, 35, 245-259.

Wheater H. and Evans E. (2009). Land use, water management and future flood risk. Land Use Policy, 26, 251-264.

Wicke B., Sikkema R., DornburgV. and Faaij A. (2011). Exploring land use changes and the role of palm oil production in Indonesia and Malaysia. Land Use Policy, 28, 193-206, DOI: 10.1016/j.landusepol.2009.08.019. 


\section{APPENDIX}

The FAO Penman-Monteith equations were used to produce the ET data in Table A1 reported by the Royal Irrigation Department

(2011). ET was calculated with weather data from 120 weather stations within 64 provinces from 1981 to 2010 . ET。 data was reported by the Royal Irrigation Department (2011).

Table A.1. Reference evapotranspiration by Penman - Monteith (ET $)$ of each province from 1951-1995 (45 years) in the northeastern region

\begin{tabular}{|c|c|c|c|c|c|c|c|c|c|c|c|c|}
\hline $\mathrm{ET}_{0}$ (mm/day) & Jan & Feb & Mar & Apr & May & June & July & Aug & Sep & Oct & Nov & Dec \\
\hline Nong Khai & 3.11 & 3.78 & 4.62 & 4.62 & 4.03 & 3.56 & 3.51 & 3.41 & 3.51 & 3.63 & 3.31 & 3.04 \\
\hline Loei & 3.28 & 4.06 & 4.81 & 5.06 & 4.43 & 4.07 & 3.66 & 3.55 & 3.55 & 3.55 & 3.23 & 3.04 \\
\hline - Loei agricultural station & 3.19 & 3.95 & 4.73 & 4.76 & 4.2 & 3.89 & 3.87 & 3.39 & 3.84 & 3.5 & 3.42 & 3 \\
\hline Udon Thani & 3.32 & 4.07 & 4.85 & 5.21 & 4.56 & 4.08 & 3.71 & 3.55 & 3.61 & 3.73 & 3.7 & 3.22 \\
\hline Sakon Nakhon & 3.44 & 4.09 & 4.87 & 5.02 & 4.4 & 3.99 & 3.57 & 3.44 & 3.86 & 3.9 & 3.64 & 3.25 \\
\hline - Sakon Nakhon agricultural station & 3.14 & 3.75 & 4.48 & 5 & 4.36 & 4.26 & 3.86 & 3.69 & 3.98 & 3.77 & 3.38 & 3.09 \\
\hline Nakhon Phanom & 3.33 & 3.86 & 4.3 & 4.5 & 3.95 & 3.47 & 3.42 & 3.33 & 3.48 & 3.6 & 3.6 & 3.16 \\
\hline - Nakhon Phanom agricultural station & 3.52 & 4.03 & 4.48 & 4.96 & 4.28 & 4.25 & 3.81 & 3.32 & 3.83 & 3.57 & 3.59 & 3.25 \\
\hline Khon Kaen & 3.65 & 4.18 & 5.09 & 4.97 & 4.67 & 4.29 & 3.88 & 3.68 & 3.61 & 3.79 & 3.83 & 3.63 \\
\hline - Khon Kaen agricultural station & 3.2 & 3.81 & 4.48 & 4.76 & 4.25 & 3.91 & 3.88 & 3.36 & 3.48 & 3.59 & 3.48 & 3.18 \\
\hline Mukdahan & 3.65 & 4.18 & 5 & 5.15 & 4.11 & 3.64 & 3.56 & 3.43 & 3.57 & 3.8 & 3.95 & 3.53 \\
\hline Mahasarakham & 3.57 & 4.19 & 4.71 & 5.22 & 4.62 & 4.22 & 3.84 & 3.64 & 3.62 & 3.76 & 3.83 & 3.58 \\
\hline Kalasin & 4.15 & 4.89 & 5.4 & 5.45 & 4.8 & 4.32 & 4.22 & 3.65 & 3.71 & 4.06 & 4.3 & 4.1 \\
\hline Chaiyaphom & 3.6 & 4.2 & 5 & 5.12 & 4.47 & 4.13 & 3.77 & 3.61 & 3.6 & 3.78 & 3.89 & 3.51 \\
\hline Roi-et & 3.49 & 4.13 & 4.66 & 4.83 & 4.22 & 3.9 & 3.84 & 3.64 & 3.61 & 3.63 & 3.68 & 3.51 \\
\hline - Roi-et agricultural station & 4.04 & 4.44 & 4.92 & 5.25 & 4.59 & 4.62 & 4.21 & 3.9 & 3.6 & 3.78 & 4.1 & 3.9 \\
\hline Ubonrajthanee & 4 & 4.53 & 4.93 & 5.03 & 4.45 & 3.96 & 3.87 & 3.71 & 3.43 & 3.71 & 4.23 & 4.22 \\
\hline - Ubonrajthanee agricultural station & 3.63 & 3.68 & 4.23 & 4.13 & 3.65 & 3.64 & 3.56 & 2.87 & 3.22 & 3.34 & 3.64 & 3.42 \\
\hline - Srisakad agricultural station & 3.4 & 3.92 & 4.56 & 4.75 & 4.42 & 4.43 & 4.19 & 3.71 & 3.85 & 3.62 & 3.79 & 3.45 \\
\hline Nakornrajchasrima & 3.37 & 3.95 & 4.39 & 4.64 & 4.2 & 3.95 & 3.89 & 3.79 & 3.36 & 3.42 & 3.51 & 3.41 \\
\hline - Pakchong & 4.71 & 4.71 & 5.01 & 4.81 & 4.2 & 4.54 & 4.26 & 4.04 & 3.38 & 3.5 & 4.44 & 4.52 \\
\hline Chockchai & 3.47 & 4.21 & 4.68 & 4.74 & 4.09 & 4.18 & 3.82 & 3.72 & 3.31 & 3.6 & 3.57 & 3.42 \\
\hline Surin & 3.76 & 4.36 & 4.83 & 4.87 & 4.21 & 4.12 & 3.71 & 3.61 & 3.62 & 3.7 & 3.84 & 3.8 \\
\hline - Surin agricultural station & 3.52 & 3.97 & 4.38 & 4.56 & 3.96 & 3.98 & 3.53 & 3.45 & 3.58 & 3.6 & 3.67 & 3.43 \\
\hline - Tha Tum & 3.54 & 4.2 & 4.78 & 4.99 & 4.43 & 4.03 & 3.96 & 3.52 & 3.55 & 3.72 & 3.89 & 3.62 \\
\hline Bureerum & 4.17 & 4.81 & 5.27 & 5.49 & 4.74 & 4.66 & 4.14 & 3.67 & 3.64 & 3.86 & 4.12 & 3.98 \\
\hline - Nangrong & 3.62 & 4.16 & 4.81 & 4.94 & 4.38 & 4 & 3.94 & 3.55 & 3.6 & 3.75 & 3.92 & 3 \\
\hline
\end{tabular}

